Wilfrid Laurier University

Scholars Commons @ Laurier

Luther Faculty Publications

Martin Luther University College

Summer 2010

\title{
Empire, Eschatology and Stolen Land
}

Allen G. Jorgenson

Waterloo Lutheran Seminary, ajorgenson@luther.wlu.ca

Follow this and additional works at: https://scholars.wlu.ca/theo_faculty

Part of the Indigenous Studies Commons, and the Religious Thought, Theology and Philosophy of Religion Commons

\section{Recommended Citation}

Jorgenson, Allen G. (2010) Empire, Eschatology and Stolen Land. Dialog: A Journal of Theology 49(2), 115-122. DOI: 10.1111/j.1540-6385.2010.00515.x

This Article is brought to you for free and open access by the Martin Luther University College at Scholars Commons @ Laurier. It has been accepted for inclusion in Luther Faculty Publications by an authorized administrator of Scholars Commons @ Laurier. For more information, please contact scholarscommons@wlu.ca. 


\section{Empire, Eschatology and Stolen Land ${ }^{1}$}

\section{Introduction}

Empire is not merely an intellectual construct explaining a state of affairs. Empire is a goal with a modus operandi that leaves chaos in its wake. Empire as such is sometimes patent but more often not, and so all the more insidious. Empire pits parents against children, the government against the people, people against land, and time against space. It is this latter that especially interests me as I pursue the utility of the doctrinal locus of eschatology for a faithful response to the demon of empire. In so doing, I first explore eschatology with an eye on space. Here I am especially interested in the notion of kairotic space as a means of God's self communication in grace. After further exploring spatial eschatology and the leverage inherent in it for countering empire, I revisit eschatology in temporal terms. In so doing, I ponder anew the gift of the pause as an especially potent resource for response to empire. In so doing, I bring these insights together in exploring a faithful Christian response to a question that must be answered by a church that too often buttresses a secularized eschatology: how can we be the church on stolen land?

\section{Eschatology and Space: Forgotten Friends}

Empire sets the context for thinking anew about eschatology. We feel the consequences of empire in many and various ways on a daily basis: climate change, greedy security at 'borders,' outsourced factories, et cetera. Empire can be variously described, but two significant markers of empire are its propensity for totalization and rationalization. ${ }^{2}$ Totalization points to the mania of empire for the expansion of its sphere of influence to the end of the eradication of borders (this very expansion being funded by the proliferation of borders/walls/prisons within). Rationalization points to empire's operational strategy: the utilization of instrumental reason that sacrifices the pursuit of truth to a mania for efficiency (which results in an explosion of rules buffered from critique by patriotic sentiments). In certain ways, the doctrinal locus of eschatology enables us to respond to these markers, especially as we think about eschatology first through space and then through time in a new way. In sum, not only does empire set the stage for thinking about eschatology, but eschatology finally returns the favour. But first I explore what I mean by thinking about eschatology through space.

Eschatos, while most often thought through the conception of time, can also be described by place: 'perhaps to be understood locally of the place in the farthest corner." Eschatos, then, names the limit, or the outside edge as well as rank and time. However, we tend to think about eschatology wholly within the framework of time. This may well betray a broader propensity to privilege time over space in occidental thought. ${ }^{4}$ Recently, this 'hegemony' of time has been challenged in reflections on eschatology. Two significant examples of this challenge are found in the writing of Kathryn Tanner and Vítor Westhelle. Tanner argues for a de-temporalized eschatology, one in which the eschatos 'may mean ultimate - the highest good that consummates creation-in which case nothing much is indicated directly about the time of the eschaton's occurrence. ${ }^{5}$ This re-framing of the eschatological question allows Tanner to see eschatology, like creation, in an altogether different

guise. Just as creation is no longer all about beginning, neither is eschatology all about ending. ${ }^{6}$ 
Creation points to our relation of dependence: all comes to us as a gift from God. Eschatology, however, references a surplus beyond creation. Eschatology awakens us to the realization that life is given to us by God, made complete in Christ and lived in the illumination of imperishability. ${ }^{7}$ While the focus of Tanner is on the identification of eschatos with rank (the 'ultimate'), rather than space, she is not uninterested in a spatial apprehension of eschatos. This latter, however, comes to the fore in the thought of Vitor Westhelle. For Westhelle, eschatology is a 'discourse on liminality." This stands in contrast to two other popular means of understanding eschatos: as temporal and as transcendental to both time and space; as imminent in progress and as other-worldly. ${ }^{9}$ Westhelle sees in this reclamation a powerful corrective in response to the propensity to locate eschatology in time alone, in service of a sacralisation of progress. Both of these thinkers develop their eschatology in response to a strong predisposition to understand eschatology in service of time. As we proceed, it is prudent to ask why theology has privileged time and what is at stake in unsettling this propensity.

Certainly Westhelle is correct in locating our tendency to temporalize eschatology as a result of our propensity toward progress. Yet surely there is more to it than this. Discourse on eschatology throughout the history of the church has tended to privilege time over space. Perhaps we can find a foundation for such a prejudice in theological apprehensions of Greek thought as generally understood. Plato is commonly seen to eschew becoming for the sake of being, the result being that the shifting sands of time are markers of 'being' at a lower level. Because being per se seems beyond the reach of mere mortals, a fixation on markers of our fallenness is inevitable. When one is ever looking over the shoulder at becoming, time becomes the principal lens through which one reads reality. The study of history can then become an attempt to fix the fluidity of time and to rein it in. Of course, things are never quite so simple. Space is never completely left behind in thinking through time. Time is sketched in lines or a circle in order to make sense of it in such a way that demonstrates Aristotle's assertion that all knowing comes through the senses. I cannot see time, but I can see a circle and a line, and imagine how time moves on these symbols. Yet Aristotle's attention to time, both as a counter point to Plato's doctrine of the forms and as a foundation for his treatment of causality, point to time as the fundamental category for thought. ${ }^{10}$

It seems, then, that both Plato and Aristotle play into our preference of time over space. It is not too surprising that Christian thought tends to use time as a primary concept in eschatology. This malady, then, is deep seated. Yet the tonic for this prejudice lay deeper still. The older testament, in particular, invites ways of imagining God's being with us that attend to space via narrative. Indeed, place itself sometimes seems to move forward in the first testament: a burning bush makes a space sacred, the promise of land renders it holy, a cubic place on earth mimics heavens halls. There is something sacred about space itself in the New Testament's forebear. Yet certain space has particular potency. This space I call kairotic.

\section{Kairotic Space}

Kairos is familiar to us from eschatological discourse. It stands over against chronos, which is that sort of time that is predictable, ordered and important in its own right. Kairotic time is time of crisis and revelation. Perhaps one of the failures of the Christian church over time has been to cheapen kairos by domesticating it. ${ }^{11}$ When kairos becomes something that one can predict or plan-a concept 
without reserve-it loses its imaginative potency. Yet this is not the only way that kairos has lost its purchase for those on the sacred way of Jesus. We have also gone astray by losing sight of the intersection of time and space, as narrated in both testaments. This intersection is especially clear in the cross and resurrection. The cross is that place where we point to the crucified God's decision to experience the terminus of time as a human. The tomb is that space that points to the crucified God's initiation of the divine reign for every time.

The cross and resurrection moor our own experience of the ebb and flow of the eschatos. The eschatos is revelatory in both space and time: the end of both space and time is the apprehension of the whole. This is most clear to us with respect to time. When the story ends, sense is made of the beginning and the movement from alpha to omega. How, then, is this the case with respect to space? What is the alpha of space, and what is the omega of space? Scripture narrates alpha space as Ur, Egypt and Babylon and omega space as the promised land. Alpha and omega are related by a between defined by promise. The space between is a space rich with God in the guise of covenant. I move from cradle to grave under the aegis of promise. Space, then, also opens us to God's selfgiving and invites us to re-visit space's sacramental potency. To put it in the words of Luther as paraphrased by Brenz:

Just as before God a thousand years are only a moment, even less, as Peter writes, II Peter 3 $[: 8]$, ' a thousand years are as one day,' so a thousand places before God must also be as only one place, yes less than one place. Since Christ has ascended to another world with his heavenly Father, outside of this world in which places have their meaning, even though in particular he is in heaven and on earth, he is consequently not in two places but only in one place because heaven and earth are only one place before God, and it is only in our finite view that they are separated so far from one another. ${ }^{12}$

Sometimes a place opens up to us this sacred potency. Space can open up to us, fleetingly, God's view of wholeness. We want to sacralise such space and thereby betray our tendency to domesticate space. Too often the church mimics empire's desire to coerce space, including empire's propensity to establish firm borders-both within and without. ${ }^{13}$ By carefully crafting a place for discerning who is in and who is out, empire locates borders as contours of identity. Walter Brueggeman notes that 'empire never seems to learn that brutal expansion has no future. ${ }^{14}$ Empire has ordered space by way of artificial borders to the end that it over-expands; collapsed by the greed that is its dynamism. ${ }^{15}$

The church can respond to empire by revisiting the sacred potency of space. Above all, we affirm the potency of space by learning to look to liminal spaces for the epiphany of God. ${ }^{16}$ Here, then, the identity of limit as border is upended. Limit draws near to center. ${ }^{17}$ We learn to begin at the edge, because the edge is where the center is found, where Christ is. For those who look outward, the limit becomes the center. Kairotic space radically re-orients occidental sensibilities.

In sum, we need to return again to the truth of the intersection of time and space. Investing space with meaning need not mean denying the revelational potential of time, yet it most surely will reframe it. As Kathryn Tanner notes, even for those who are interested in a de-temporalized eschatology, the realization of the divine gifts for those yet in the world still takes time. ${ }^{18}$ We turn, now, to imagine how an eschatology spatially re-imagined reframes the church's understanding of time in response to empire. 


\section{The Pause between Now and Then}

Among the most influential forces in contemporary thought has doubtlessly been Martin Heidegger. Heidegger put the future on the agenda of modern thought, taken up in a particular way by theology. Being-toward-death was interpreted as a secular version of a deeper theological truth that was read by theologians of hope as the eschatological affirmation of life after death: a proleptic breaking in of the reign of God. It is not uncommon to hear theologians laud the future as the key theological category to respond to the challenges of modernity. This is not an insignificant intuition. As Douglas John Hall has noted, in contemplating their end both institutions and individuals become more interesting. ${ }^{19}$ This is an important truth that the doctrinal locus of eschatology-as temporally received-communicates. Here, however, I want to imagine another way to read eschatology temporally; one that is informed by a spatial apprehension of eschatos in service of responding to empire.

In revisiting eschatos via space, I underscored the alpha of space as here and the omega of space as there. These two invite us to imagine the space between here and there. Often we imagine the between as a problem to be solved - a barrier that bars. This is because the future has been divinized in our thought. Yet eschatology attentive to both time and space is quite content to acknowledge both as created. ${ }^{20}$ This de-divinization of time and space allows us to receive both as gift: the eschatos is no more present in the future or the there than in the now or the here. The eschatos accompanies us in our journey from here to there, from now to then. This is no reason to refuse to move from here to there or from now to then. The eschatos travels with us: it moves. In fact, not to move with it is to die. Movement is a necessary and blessed event, then. This transforms our apprehension of the between. The between is where my now and then, my here and there meet. The between is the space relating here and there. Time's correlate of space's 'between' is the pause.

A pause, then, is a temporal 'between.' It is silence in voice. It is Sabbath in work. It is dreaming during the day. Empire, of course, has no use for any of this. When rationalization is the modus operandi of the nation, efficiency experts outlaw day dreaming, encourage Sabbath shopping and make muzak the order of the day. Empire is especially suspicious of poets, those masters of the pause who recall the cadence of life and invite cogs to abandon wheels so as to be attentive to the transition from now to then, from here to there. Poets invite us to get lost in the silence that makes notes into music. They seduce us into the delight of walking, so that we might experience movement itself as an epiphany, discovering in creation a self-giving of God. ${ }^{21}$ Poets remind us that rhetoric rich with ponderous pauses is not antithetical to truth. How we speak says something. The poetry of Jesus reminds us that attention to cadence cracks open truths that remain hidden to those who have no interest in the pause, in the Sabbath, in rest.

Pause is empire's greatest enemy. ${ }^{22}$ Empire works overtime to eradicate rest. Empire is restlessness writ large. Empire is our refusal to be where we are. It is a rebuttal of limits and so a desire to sacrifice space to time, which is precisely what cyber-space is. Too few of us know where we are, and technology is only too glad to enhance our ignorance. A recent article by Alex Hutchinson in The Walrus pointed to the manner in which the use of Global Positioning Systems has resulted in the diminishing capacity of that part of the brain used in determining our bearing. ${ }^{23}$ Of 
course, it can be argued that a GPS is nothing more than a map. Yet the provenance of a piece of technology is of a piece with its modus operandi. Global position systems were created for

surveillance. Surveillance is a preoccupation with where the other-as-enemy is. The gospel responds to this preoccupation by alerting us to where we are: this is the beginning point for thinking through space and this takes time. There is no time for this in empire, and increasingly there is no time for this in the church.

The church has no idea of the degree to which it has been habituated in the ways of empire. We are desperately in need of poets, artists and choristers to shake us awake. Without the space and time needed to be creative, the church slips ever deeper into the Zeitgeist. The church manufactures a self-identity that denies the gospel: the church becomes the gospel. Once this fatal move has been invoked much hand-wringing follows. How will we grow? How will we become relevant? This question is so critical because if we are not relevant we will not grow and if we do not grow we will die and if we die the 'gospel' has failed. Of course, no one will say this. None of us will confess that this is where our thoughts lead. Yet precisely this pattern of thought presents itself in annual meetings, in church wide assemblies, and in halls of the ecclesial academy. We need to face up to this anathema. But is it really possible to take time and space for creative thought in light of the very real financial exigencies that we face? Is it really possible for pastors to leave their computers to walk around their neighbourhoods? Is it really possible for theologians to turn off their Blackberries and iPods in order to enter silence? Is it really possible for the church to be where it is, to sacrifice that mania for expansion that only confirms the truth that the church refuses to face: we are dying, yet die we must. If the story of Jesus tells us anything, it tells us that Christological existence is a sacrifice of our plans. Ever and always again we fall as our plans fail. It sometimes seems to me that the church has betrayed the word fall by linking it inexorably to the exodus from Eden. Falling, however, is the vocation of the faithful. We fall into the arms of the Lord, we fall into the future, we fall in love, we fall because falling is part of the human condition. Falling names the risk that empire refuses because empire wills not to fall. But empires fall more certainly than they rise. Falling is truly a gift.

It is, of course, right headed to respond to all of the above with the insight that Luther and company use to counter what they conceived to be a free-form spirituality of the Anabaptists. Luther's affirmation of the ordinary means accepting the timetables that are a reflection of the waxing and waning of the seasons that produce the bread and the wine of our Eucharistic life. Indeed, I want to affirm this rebuttal, because this rebuttal contains the very thing that the church so desperately needs to rediscover: one cannot harvest year round. ${ }^{24}$ Unfallowed land-land stripped bear of nutrients - only produces by being artificially fed the chemicals that agri-corporations so gladly sell. But any farmer worth her salt knows that this raping of the land cannot continue. Land demands rest. It preaches a pause to us every winter even while we refuse to listen. The land pleads with us to enter a Sabbath rest. The land knows that this is the lynch pin on which an ecclesial repentance from empire turns. Too often, however, the church refuses to repent. The church wills not to listen to the land. The church will not rest with the land. Why is this? The church will not listen to the land because we know that the quiet of pause will bring to the fore an uncomfortable truth: we rest on stolen land.

\section{Earth Turning Truths}


I write this article on stolen land. During periods of expansion in the interior of what is now Canada, indigenous peoples were allotted land under a variety of agreements. British administrators in Quebec negotiated with the Ojibway north of Lake Ontario and granted them and other members of the Six Nations a tract of land of 950,000 acres in $1784 .{ }^{25}$ The property was defined by the Grand River. Property within a six mile boundary of each side of the river was given them. Our home sits within that six mile limit. Today First Nations communities inhabit 48, 000 acres of the original property. The story of the procurement of the bulk of this property by Whites is uncertain. What is certain is that Aboriginals were taken advantage of in land sales. ${ }^{26}$ Across North America, of course, this is but one incident in a broader pattern of activity. It has been suggested that in the United States of America, First Nations have a legitimate claim to two-thirds of the land mass. ${ }^{27}$ The land that remains in Aboriginal communities is under constant assault-both politically and ecologically. George Tinker notes that all the nuclear testing that has taken place in the United States of America has taken place on the land of indigenous peoples. ${ }^{28}$ Today, the land that remains in Aboriginal communities is in an ever tenuous status because of North American policies that disenfranchise Aboriginals by narrow definitions of 'Indian' identity. All of this, of course, can become something of an abstraction. For this reason, I find it important to remind myself, that when I step in my back-yard and watch cardinals flicker across my view; when I dig in our garden to plant annuals in the spring; when I sit in the shade of pine trees I also sit and dig and delight on stolen property. I dare not forget this. Moreover, I dare not forget that my home parish also sits on stolen land.

These are uncomfortable truths. Yet, if we face them with our First Nations neighbours, perhaps we can begin to be where we are; perhaps we can again enter into relationship with the land. So, then, what lessons are there for our learning from our First Nations neighbours? To begin with, they remind us of truths that we know from our own tradition but have buried in certain occidental sensibilities:

Aboriginal elders have consistently admonished their leaders and their people to exercise great caution in the ways they formulate or conceptualize political entities or sovereign authorities. Their concern, in large part, arise from the fundamental belief that absolute sovereign and absolute sovereign authority exist and can only exist in the Creator. For that reason, the Creator is referred to as Oti pi itchi Gew — the One who owns all things — or as Wiyo Taw Wi Maw. Cree elders believe that a people can only derive sovereign power and sovereign authority from the Creator. That power or authority is inseparable from the particular relationship that exists between the people and the Creator. ${ }^{29}$

Joerg Roeger has rightly noted that a fundamental aboriginal insight, then, is that one cannot own the land. ${ }^{30}$ Moreover, his insight that 'we live in a country that is built on a history of expropriated land' is doubly true in that we impose our notion of ownership to First Nations people so that it would be possible for us to 'expropriate' such land. ${ }^{31}$ Here, Aboriginal Americans have a fundamental insight regarding land that is of profound utility for a church that wants to counter empire. But are we ready to listen to our neighbours? Unfortunately the history of Christianity in North America is not one of listening well:

Indians, it seemed, could offer little inspiration or example to civilized humans, and colonists saw little need to examine either the Indian or Indian culture. Indian government was a labyrinth, confused and indecipherable. Indian religion was absurd and ridiculous. 
Jonas Johannis Michaluis, in a letter to the Reverend Adrianus Smoutuis, summed up the feelings that most colonists had for Indians when he described them as 'savage and wild, strangers to all decency, yea, uncivil and stupid as garden poles.'

'Stupid as garden poles.' It's funny, isn't it? And a little annoying, too. But there's no point in being angry. These are just the sounds and smells of empire-fear, racism, greed, arrogance — and since empire tends to be exclusive, it makes sense, doesn't it, that Indians would not be welcome? ${ }^{32}$

If empire is fear, racism, greed, and arrogance then it is countered by faith, openness, generosity and humility. These are lessons not easily learnt, yet our Aboriginal neighbours invite us to look to the land to tutor us so that we can be where we are. The land reminds us that we do not own it. The land reminds us that fences are made not grown. The land reminds us that rest is the condition for the possibility of the bounty that finances generosity. The land reminds us that we are not masters: not of it, nor of ourselves, nor of our charges. The land reminds us that we live by promise. Land is a promise. The land reminds us that we live between: between here and there; between now and then. The land reminds us that we live eschatologically in space as well as time. The land speaks to those whom the Creator has given ears to hear; and with those who have ears to hear, the Land reminds us that promise is enough. Promise is the modus vivendi for followers of the Way; a Way that counters the claims of empire by enabling us to be where we are; enabling us to live presently.

\section{Conclusion}

In this article, I propose that the church counter the claims of empire by being where we are. ${ }^{33}$ Moreover, I propose that in North America, this necessitates repentance in response to our treatment of indigenous Americans. In so doing, we experience God's self-giving grace as the condition for the possibility of this repentance. In North America, then, as we learn to be where we are, we discover that our location here was first afforded by a generous hospitality offered by Aboriginal Americans. French couriers did not encounter a people who refused them hospitality because these Europeans had crossed their borders. ${ }^{34}$ For the First Nations, then as now, borders are not a gift of the land, and so not particularly meaningful. ${ }^{35}$ This stands in sharp contrast to advocates of empire, who self-define by arrogant borders, by drones defiling the air, and by barbedwire fences scarring deserts. Moreover, Aboriginal refusal to self-define by border, in concert with a desire to define self by communal hospitality, results in an identity which is expansive in character. ${ }^{36}$ These are the people whom we wound even still; these are people who are not interested in our guilt, but our willingness to learn. ${ }^{37}$ Their vocation is to teach us to open up hearts, homes, and hands. God in Christ uses these prophets to call us to lives that are expansive; as expansive as those who first widened the circle to allow us in. While empire endeavours still to annex the weak, indigenous Americans invite us to be where we are: in an ever widening circle that is a prayer for the harmony of all, for respect for creation and for a deep and abiding joy in living before our Creator. 
1 Allen G. Jorgenson, Assistant Dean and Associate Professor of Systematic Theology, Waterloo Lutheran Seminary, Waterloo, ON, Canada.

2 Cf. Allen G. Jorgenson, 'Mutuality, Kenosis and Spirited Hope in the Face of Empire' in Being the Church in the Midst of Empire, Karen L. Bloomquist (ed.) (Minneapolis: Lutheran UP, 2007). 163-177.

3 Cf. 'eschatos' in A Greek-English Lexicon of the New Testament and Other Early Christian Literature, Second Edition Revised and Augmented by F.Wilbur Gingrich and Frederick W. Danker from Waler Bauer's Fifth Edition, 1958 (Chicago: University of Chicago Press, 1979), 313.

4 George E. 'Tink' Tinker, American Indian Liberation: A Theology of Sovereignty (Maryknoll: Orbis Books, 2008$), 7$.

5 Kathryn Tanner, 'Eschatology and Ethics,' in The Oxford Handbook of Theological Ethics, eds. Gilbert Meilaender and William Werpehowski (Oxford: Oxford University Press, 2005), 44.

6 Ibid., 47.

7 Ibid.

8 Vítor Westhelle, 'Liberation Theology: A Latitudinal Perspective,' in The Oxford Handbook of Eschatology ed. Jerry L. Walls (Oxford: Oxford University Press, 2008), 312.

9 Cf. ibid, 323. The other two are not to be denigrated in Westhelle's estimation.

10 Cf. Martin Heidegger, Der Begriff der Zeit (Tübingen: Max Niemeyer Verlag, 1995), 8: 'Die Zeit is das, worin sich Ereignisse abspielen. So wird dieses schon von Aristoteles gesehen im Zusammenhand mit der Grundart des Seins des Naturseins...'

11 This concern is behind much of Luther's critique of the Latin Mass as he understood it: liturgy has gone wholly amuck when it intends to orchestrate divine favour.

12 Martin Luther, Martin Luther's Works, Volume 38, ed. and trans. Martin E. Lehmann (Philadelphia, Fortress Press, 1971), 77.

13 Jorgenson, 'Mutuality, Kenosis and Spirited Hope in the Face of Empire,' 164.

14 Walter Brueggeman, 'Alien witness: How God's people challenge empire' in Christian Century (March 6, 2007$), 30$.

15 Tinker, American Indian Liberation, 31.

16 Mary Philip, 'The Space in Between Spaces: The Church as Prophetic Pest/Parasite,' in Being the Church in the Midst of Empire, 95-98.

17 Cf. Dietrich Bonhoeffer, Dietrich Bonhoeffer's Works, Volume 3, Creation and Fall, ed. John W. De Gruchy, trans. Douglas Stephan Bax (Minneapolis: Fortress Press, 1997), 86: 'God is at once the boundary and center of our existence.'

18 Tanner, 'Eschatology and Ethics,' 51.

19 John Douglas Hall, 'Preaching to People with Cancer: The Eschatology of the Body,' Journal for Preachers (Lent, 2006), 30, 31 .

20 It is for this reason that Aquinas can write: 'In creation, therefore, neither motion nor change exists.' Cf. St. Thomas Aquinas, Summa Contra Gentiles, Book Two: Creation, trans. James F. Anderson (London: University of Notre Dame Press, 1975), 54. Time and space are the result of creation because creation proper is an eternal event.

21 Martin Luther, 'The Large Catechism, in The Book of Concord, eds. Robert Kolb and Timothy J. Wengert (Minneapolis: Fortress Press, 2000), 431.

22 Pause, of course, is not antithetical to protest, but is rather the condition for protest's possibility. Thanks is due Oscar Cole-Arnal for coffee-pause conversations that have afforded me this and other insights.

${ }^{23}$ Cf. www.walrusmagazine.com/articles/2009.11-health-global-impositioning-systems (Accessed January 29, 2010).

24 Alas this truth is lost on too many people insofar as too many have altogether lost connection to the land. Many thanks to Rob Fennell for a helpful conversation around this and other themes related to this article.

25 Robert Bothwell, The Penguin History of Canada (Toronto: Penguin Canada, 2006), 122. Cf. also http://www.sixnations.ca/LandsResources/HaldProc.htm (accessed January 1, 2010) for a copy of the 'The Haldimand Proclamation of 1784' and further resources related to the loss of this property by the Six Nations.

26 Reflecting different understandings of the roles that Treaty play and drastically opposing views regarding the nature of land in aboriginal and occidental thought.

27 Tinker, American Indian Liberation, 81.

28 Tinker, American Indian Liberation, 58. 
29 Harold Cardinal, 'First Nations sovereignty and Native Liberation: Okimaw Win and Post-Colonial Nation-Building,' in Intersecting Voices: Critical Theologies in a Land of Diversity, eds. Don Schweitzer and Derek Simon (Ottawa: Novalis, 2004), 195. Cf. Also ibid, 197 where Cardinal underscores that 'ownership' is a sacred trust.

30 Joerg Rieger, "God and Power, Prophets, and Native Lands" in Theology That Matters: Ecology, Economy and God ed. Darby Kathleen Ray (Fortress, 2009), 69.

31 Ibid., 60.

32 Thomas King, The Truth about Stories: A Native Narrative (Toronto: House of Anansi Press, 2003), 76, referencing J. Franklin Jameson, ed., Narratives of New Netherlands (New York: Barnes and Noble, 1967), 126.

33 Cf. Ludwig Wittgenstein, Culture and Value, trans. Peter Winch (Chicago: University of Chicago Press, 1980),

7: 'For the place I really have to get to is a place where I must already be now.'

34 Cf. John Ralston Saul, who develops the provocative thesis that Canada's 'single greatest failure... has been our inability to normalize — that is, to internalize consciously — the First Nations as the senior founding pillar of our civilization.' (A Fair Country: Telling Truths About Canada (Toronto: Viking Canada, 2008), 21)

35 King, The Truth About Stories, 102.

36 Saul, A Fair Country, 4.

37 Tinker, American Indian Liberation, 47. 